\title{
Book Review. Győrfi Dénes's Bibliotheca Universitatis Claudiopolitanae. Evoluția instituțională și practici ale lecturii în Clujul Universitar
}

\author{
ARTÚR LÓRÁND LAKATOS \\ Affiliation: Partium Christian University \\ Department of Economics, Oradea, Romania \\ Email: lakatosartur@partium.ro
}

\begin{abstract}
This book review is presenting a published $\mathrm{PhD}$ thesis concerning the history of the library of the university of Cluj, from its foundation until 1945. The book is dealing with three distiguishable periods, the 1872-1918 period, during the Austro-Hungarian Monarchy; the period of 1918-1940, the era of the Great Romania, and the third period is represented by the years of World War II. Based on a rich bibliography, the author is following the major processes concerning the institutional management of the library.
\end{abstract}

Keywords: library history, library management, cultural institutions, acquisitions

It is rare to meet books that are relevant both in the field of library history and library management. A librarian and researcher in history, Dénes Győrfi took this challenge by trying to give a comprehensive image to the development of the University Library of Cluj. Since he is not only a historian-taking his PhD with the subject of this current book-but also a librarian and a library manager, he has an inside look, as a professional, on the processes. In the postface of the book, the former director of the library, Doru Radosav summarizes the author's efforts in the following way: it is a typical text of historiography, with deep analyses in the subjects of library functions, infrastructure, finances, personnel and the profession of a librarian, with all of its tasks and hardships.

A few stylistic generalities can be observed. First of all, the author uses simple notions to make the text clear for a larger audience. Since the subject is relatively neutral, the author can try to stay objective to present facts and processes without making value judgments. 
In this respect, the quest for the complex character of the text is accompanied by a certain rigorous writing style. Each and every sentence is calculated, contains precise information, allowing very limited space for subjectivity, and the formulation is cautious. Even when he narrates debatable events-like the competition for the position of the director of the library from 1929, accompanied by serious conflicts of ambitions and interests-he resumes to present the facts discovered in the documents: the author allows the sources to speak for themselves. In many cases, we can learn some very interesting details and case studies, like the struggle for controlling the library at the end of the twenties, when the administration of the kingdom of Romania was already properly established, and a harsh struggle between different interest groups was going on. This can be observed especially in the political and economic life, where stakes were higher, but they did not avoid the otherwise very neutral institution of the University Library either. A typical scene took place between director Eugen Barbul, and his later successor, Ioan Mușlea, this second one being supported by the influential professor Alexandru Lapedatu. Other actors were also involved, one of them being so determined to obtain the post of the director that, through his practices, he managed to cause disciplinary actions against himself. This story is a great cross-sectional case study of how relations in the Transylvanian elite of those years were shaped.

The history of the modern University of Cluj, and through this, the history of the university library, has some distinct periods, divided according to the main turning points of the history of East-Central Europe. First, there is the period of the Franz Joseph University, founded in the Austro-Hungarian Monarchy in 1872. This era ended in 1918 when the Franz Joseph University was forced into exile due to the advancement of the Romanian troops, and the King Ferdinand University was established, taking over the goods of the former Hungarian state university. The King Ferdinand University was continuously developing in the city, while the Franz Joseph in Szeged was using continuously the brand of the University of Kolozsvár, practically, two universities claiming the city brand for themselves. The third period starts in 1940 when, according to the Second Treaty of Vienna, Northern Transylvania was annexed back to Hungary, the Romanian university choosing the way of exile in Sibiu. Following the end of World War II, in 1945 the ethnic aspect of the issue of continuity was solved in a seemingly Solomonic decision: the Romanian university returned from Sibiu, and a state university for the Hungarian minority from Romania was founded by a Royal Decree, the Bolyai János University. The two universities existed in parallel for a while, for being unified forcefully in 1959. This was followed by a gradual reduction of the Hungarian element in the new, unified structure, a process reversed 
only after the revolution of 1989, nowadays the Babeș-Bolyai University claiming proudly the brand of multiculturalism. Even if the University Library theoretically is a separate legal entity from the universities themselves, in practice, it is affected by the changes undergoing in the political, legal, social and economic status of the University: moreover, the same major events have a significant and similar impact over them. In this sense, the different periods in the existence of the University Library often reproduce the same phenomenon, especially on a professional plan-acquisition, research, human resources-issues that generally share the same characteristics, under all kinds of regimes and are affected by the general political, social economic and cultural environment. This book deals with three of these periods of existence: the 1872-1918 period, the 1918-1940 period, and the 19401945 period. In this latter one, the author follows the parallel fate of the collections from Cluj and Sibiu until their moment of reunification in 1945.

The author did his best to gather as many sources as possible. From the category of studies and articles, 24 titles are included in the bibliography, the oldest one from 1894. Many of the authors of these articles are either people directly involved in the management of the library or historians dealing with local and regional subjects, including intellectual and cultural history. Similar is the case of the books and monographs, but also a series of publications that can be considered primary sources, like memoirs, journals, and letters. Such are the monograph of the former library director, Eugen Barbul, the memoirs of Farkas Gyalui, the journal and letters of Lajos Kelemen. Győrfi did a good job by reviewing the periodical publications related to the history of the library-many of them being the publications of the institution-but probably the most important category of texts are the yet unpublished archive materials.

The author performed comprehensive research in different archives from Cluj and Budapest, starting with the document collection of the library. The most important sources are, however, those coming from certain personal collections. Of the 320 pages of text, almost half of it is dedicated to the transcript of important and illustrative documents and to pictures that better clarify the historical and institutional context to the interested reader.

The text is divided into four parts of different sizes. The first part is focusing on the evolution of the newly founded University Library in the period of 1872-1918, from its establishment till its situation in 1918. The author is presenting here different issues related to the maintenance and development of the library, starting with its foundation, and the issue of its location until the building of the current Central Library, a building 
where the headquarter of the institution is functioning even today, and seemingly this will remain so for a while. A separate chapter deals with the issue of the establishment of the smaller deposit libraries near the departments of the university, subordinated to the central library. Other chapters deal with the human resource of the institution, clearly describing and delimiting the functions employed, the constant acquisitions and the growth of the library collections, and the rules of functioning. The positive role of key personalities is highlighted, like in the case of directors Károly Szabó, Zoltán Ferenci, and Pál Erdélyi. The place and activities for developing the Romaniancentered collections of Grigore Moldovan and Grigore Silași are also mentioned. The last chapter of this unit deals with the situation during World War I.

The second part deals with the development of the library in the interwar period, in Romania, when all the turbulence of the political life influenced the functioning of the institution too. This unit has three directions: one of these is reflecting on the struggle for influence among circles of interest of the academic life related to the functioning of the library. The second is related to managerial issues, from salaries to extending the access to a larger public, the building of new reading rooms, the set of rules for reading and borrowing. Finally, the third direction focuses on the enrichment of the library collections. The third unit deals with the issue of the division of the library collections following the Arbitration of Vienna: the responsible organs evacuated in Sibiu only the materials belonging to the Romanian national culture, leaving the Hungarian materials for the Hungarian university life. The last unit presents the return of the Romanian university and the way collections were unified again.

The general conclusion can be the idea formulated by István Csucsuja-in Dénes Győrfi's vision, the development of the University Library from Cluj is a process of constant ascension. We can hope, in our turn, that this ascension will continue.

\section{References}

Győrfi, D. (2019). Bibliotheca Universitatis Claudiopolitanae. Evoluția instituțională și practici ale lecturii în Clujul universitar [Bibliotheca Universitatis Claudiopolitanae. Institutional evolution and reading practices in the university city of Cluj]. Argonaut. 